J. Management and Humanity Research

Vol. 1, 2019, 53-60

ISSN: 2582-7766 (online)

Published on 18 June 2019

www.researchmathsci.org

DOI: http://dx.doi.org/10.22457/jmhr.v1a06106

Journal of

Management and

Humanity Research

\title{
College Student's on-line Shopping Addiction: A Market Survey and Statistical Analysis
}

\author{
Shuai Tang ${ }^{1}$ and Dong-shan Yang ${ }^{2}$ \\ ${ }^{1}$ School of Education, Sichuang University \\ Chengdu - 610044, Sichuang, China. \\ ${ }^{2}$ School of Economics and management \\ Chongqing University of Posts and Telecommunications \\ Chongqing - 400065, Chongqing, China. \\ Corresponding author: Dong-shan Yang, E-mail: 1654103631@qq.com \\ Address: No.2 Chongwen Road, Nan' an District, Chongqing, 400065, China \\ Received 8 May 2019; accepted 12 June 2019
}

\begin{abstract}
With the method of social investigation and statistical analysis, this paper investigates and analyzes the online shopping behavior of college students in several universities in Chongqing The prevalence of Internet shopping addiction among college students was measured. The study found that the current college students' Internet shopping addiction has been initially formed, the level of addiction is in the Middle Range, and needs the attention of students' family and school education and other relevant parties, and to formulate appropriate intervention and counseling measures.
\end{abstract}

Keywords: college students; online shopping; addiction; statistical analysis

AMS Mathematics Subject Classification (2010): 62P25

\section{Introduction}

Nowadays, Internet shopping addiction has developed into an important social problem, which has attracted much attention. In a 2011 online survey of 2,580 people conducted by the China Youth Daily, 71.1 percent of respondents said they were "addicted to online shopping." Of these, 25.6 per cent felt they had a "relatively serious" or "very serious" online shopping addiction, while 45.5 per cent said they were "a bit addicted". College students are the second largest segment of the online shopping community, whose online shopping addiction phenomenon has attracted much attention, according to the report of China's online shopping user behavior research 2012-2013 published by CNNIC. Zhang Dasheng, the vice president of the Youth Research Institute in Heilongjiang, said their survey found that "online shopping dependence" has become a common disease among many people, especially among college students, for every 100 people who buy online There are 20 people who have a tendency to "shop online". Some students on the forum of Shanghai Normal University expressed concern that they could not control their online shopping behavior. Some students said that they were more likely to have an online shopping addiction because they could not see the money entity, only saw the number changes and did not feel much. 


\section{Shuai Tang and Dong-shan Yang}

In view of this social problem, this paper attempts to make an empirical investigation and statistical analysis on the Internet shopping addiction of college students, to measure the degree of "Internet Shopping Addiction" of college students, and to put forward corresponding suggestions for management and control In order to help college students build a healthy campus lifestyle to provide a theoretical reference.

\section{Relevant literature and measurements}

At present, there are few researches on Internet shopping addiction in foreign countries, and no special academic research results have been found. Most of the existing arguments are based on the research on Internet shopping addiction, but not on the characteristics of Internet shopping addiction. However, there are still some literature on compulsive shopping and other views for reference (Whang, et al., 2003; Shaw \& Black, 2008;Rose \& Dhandayudham, 2014;Mueller, et al., 2011). According to Koran et al.(2006), 1.5 percent of people in the United States have a mental disorder similar to that of online shopaholics, while a large proportion of young people in South Korea and Taiwan have become debt-ridden "card slaves" by investing in credit cards. Lee, Lenno and Rudd (2000) have found that consumers with high compulsive personality, Low self-esteem and fantasy tend to buy compulsively. Hollander's (1993) study shows that shopping addicts, who tend to have low self-esteem, rely on shopping to boost their self-esteem.

Referring to the research on the criteria for judging Internet addiction at home and abroad, and referring to the Chinese Internet addiction scale developed by the American manual of classification and diagnosis of Mental Disorders (DSM-IV), Chen (2003) measures the degree of Internet shopping addiction of college students in three dimensions: Internet addiction, impulsive purchase and compulsive purchase. Among them, Internet addiction refers to a chronic or periodic state of infatuation resulting from repeated use of the Internet and an irresistible desire to use it again At the same time will want to increase the use of time tension and tolerance, restraint, withdrawal phenomenon, for the pleasure of the Internet will always have a psychological and physiological dependence. Impulse buying refers to an impromptu, unplanned, thought-out, and more difficult-to-suppress act of Shopping Impulsive shoppers are more likely to be emotionally attracted to the product and crave instant gratification. Compulsive buying refers to the idea of compulsive shopping before shopping, often producing negative emotions such as anxiety, and these troubles are often through shopping after the temporary relief (Meerkerk, et al., 2009; Whang, et al., 2003). The main manifestations of compulsive online shopping include: When you go to a shopping mall to see a product you like, or when there is a need to buy a product, you first think of shopping websites to search for relevant information; every time you go online, you want to browse shopping websites Almost every day you want to buy something, or you will feel uncomfortable, buying a lot of goods, whether you need them or not, and then often leaving them unused. Every time you buy something online, you have to constantly compare the reputation and prices of different online merchants Spend a lot of time, use the network shopping out of control and so on. After consulting the Chinese Internet Addiction Scale (CIIA) compiled by the American manual of classification and diagnosis of mental disorders (DSM-IV) and Chen Shu hui, and considering the actual situation of college students, we developed the dimensions and scale of college students' Internet shopping addiction as shown in Table 1. 
College Student's on-line Shopping Addiction: A Market Survey and Statistical Analysis

Table 1: Dimensions and scales of Internet shopping addiction of College Students

\begin{tabular}{|c|c|}
\hline Dimensions & Problem Term \\
\hline \multirow{7}{*}{$\begin{array}{l}\text { Internet } \\
\text { addiction }\end{array}$} & 1. I always turn on my computer when I get up \\
\hline & 2. I get bored if I can't get on the Internet every day \\
\hline & $\begin{array}{l}\text { 3. I have trouble with my eyes because I spend too much time online, } \\
\text { but I just don't want to stop }\end{array}$ \\
\hline & $\begin{array}{l}\text { 4. Because I often surf the Internet, I go shopping with my friends less } \\
\text { than before }\end{array}$ \\
\hline & 5. I get off on the Internet \\
\hline & 6. In the Internet, I can find the fun that I don't usually experience \\
\hline & 7. I actually spend more time online than I intended to \\
\hline \multirow{7}{*}{$\begin{array}{l}\text { IMPULSE } \\
\text { BUYING }\end{array}$} & 8. I find it hard to stop once I start browsing online \\
\hline & $\begin{array}{l}\text { 9. Many of the things I buy online are not practical and make me feel } \\
\text { like a waste of money }\end{array}$ \\
\hline & $\begin{array}{l}\text { 10. Every time I turn on my computer, I'm supposed to be doing } \\
\text { something else, but I can't help but go to a shopping site }\end{array}$ \\
\hline & 11. I also think about online shopping when I'm not shopping online \\
\hline & $\begin{array}{l}\text { 12. Every day I open the computer will be used to the first shopping } \\
\text { site }\end{array}$ \\
\hline & $\begin{array}{l}\text { 13. I couldn't help but go to all kinds of shopping sites and even buy } \\
\text { things I didn't need at the time }\end{array}$ \\
\hline & $\begin{array}{l}\text { 14. Once I started shopping online, it was easy to get carried away and } \\
\text { buy a lot of stuff, whether I needed it or not }\end{array}$ \\
\hline \multirow{5}{*}{$\begin{array}{l}\text { Compulsive } \\
\text { Buying }\end{array}$} & $\begin{array}{l}\text { 15. Online shopping has become my habit, every day not to go } \\
\text { shopping site will feel less of what }\end{array}$ \\
\hline & 16. I would be very anxious if I couldn't buy it online \\
\hline & 17. I don't think I could live without it \\
\hline & $\begin{array}{l}\text { 18. If online shopping is restricted (off-line, etc.), I will definitely do } \\
\text { everything possible to solve the problem and continue to shop online }\end{array}$ \\
\hline & $\begin{array}{l}\text { 19. When I buy online, if for some reason I have to stop immediately it } \\
\text { will make me very unhappy }\end{array}$ \\
\hline
\end{tabular}

\section{Data collection}

\subsection{Purpose of investigation}

In order to understand the current college students' online shopping status, including the time and money they put in, the factors influencing their online shopping behavior and so on, and to measure whether the college students' online shopping addiction exists or not, we organized and conducted this Social Survey with the ultimate goal of obtaining a quantitative analysis of the degree of Internet shopping addiction of Contemporary College students based on survey data to determine whether the social problem exists And whether or not to take active intervention or even control measures.

\subsection{Content of the investigation}

According to the scale 1, we designed the questionnaire. The final questionnaire consists of two parts. In the first part, 7 questions are set up to collect the basic information of the subjects Such as gender, grade, school, place of residence, type of urban / rural residence, 


\section{Shuai Tang and Dong-shan Yang}

proportion of monthly shopping expenses, length of daily Internet access, etc. In the second part, we set up 19 questions (19 items in the scale 1) to collect data on the subjects' Internet shopping addiction from three aspects: Internet shopping addiction, compulsive shopping and impulsive shopping This part of the question is structured, and the answer is assigned a score of 1,2,3,4,5, which in turn represents an increase in the degree of agreement They are "totally disagree" , "not quite agree" , "basically agree" , "relatively agree" and "very agree" .

\subsection{Subject of investigation}

The survey subjects were college students, so we selected several colleges and universities in the main urban area of Chongqing, including Chongqing University of Posts and Telecommunications, Chongqing Technology and Business University, Chongqing University of Technology, and Chongqing Jiao tong University A total of 500 college students were randomly selected for questionnaire distribution and recall. These students come from many provinces and regions, have different urban and rural household registration backgrounds and different family economic conditions, so it is representative to use this sample to measure the current college students' Internet shopping addiction status.

\subsection{Questionnaire collection and screening}

In the process of issuing the questionnaire, we adopted a variety of sampling methods, first of all, quota sampling, according to the size of students in school, we assigned a sample size of $140,110,130$ and 120 to Chongqing University of Posts and Telecommunications, Chongqing Technology and Business University, and Chongqing University of Technology, respectively. Secondly, the random interception on campus invited respondents to fill in the questionnaire, which was based on the respondents' voluntary filling out of the questionnaire, and on-site recycling. A total of 500 copies were distributed, 500 copies were collected, and 450 valid questionnaires were obtained after the invalid questionnaires were eliminated.

\section{Statistical analysis of data}

\subsection{Validity test of questionnaire}

The validity test is mainly based on the determination value (CR), which ranks the scores of all items in the questionnaire from high to low. The top $27 \%$ are in the high score group and the bottom $27 \%$ are in the low score group. Then independent sample t-test was used to test the difference between the high and low scores of each item, and to eliminate the items where the difference was not significant. According to the output of SPSS software, all the projects have reached the remarkable level of 0.001, and all the questions can be kept.

\subsection{Descriptive statistics of basic information}

Using tables 2 to 5 , we present some basic information about the respondents in this survey, including the distribution of the respondents' gender and household registration information, and the distribution of the respondents' time spent online each day And the distribution of the respondents' monthly spending on shopping. 
College Student's on-line Shopping Addiction: A Market Survey and Statistical Analysis

Table 2: Gender distribution of respondents

\begin{tabular}{|c|c|c|}
\hline sexuality & Number of persons & Percentage \\
\hline Male & 207 & $46.1 \%$ \\
\hline Female & 243 & $53.9 \%$ \\
\hline
\end{tabular}

Table 3: Household registration information distribution table of respondents

\begin{tabular}{|c|c|c|}
\hline Household Registration & Number of persons & Percentage \\
\hline The Eastern Seaboard & 36 & $8 \%$ \\
\hline Central Region & 99 & $22 \%$ \\
\hline Western Region & 315 & $70 \%$ \\
\hline Urban Household Registration & 176 & $39 \%$ \\
\hline Rural Household Registration & 274 & $61 \%$ \\
\hline
\end{tabular}

Table 4: Daily Internet access time distribution of respondents

\begin{tabular}{|c|c|c|}
\hline Daily Internet Time & Number of persons & Percentage \\
\hline Less than an hour & 39 & $8.6 \%$ \\
\hline 1-2 Hours & 146 & $32.4 \%$ \\
\hline 2-4 Hours & 215 & $47.8 \%$ \\
\hline More than four hours & 50 & $11.2 \%$ \\
\hline
\end{tabular}

Table 5: Distribution of students' monthly shopping expenses as a proportion of total living expenses

\begin{tabular}{|c|c|c|}
\hline $\begin{array}{c}\text { Shopping expenses as a } \\
\text { percentage of } \\
\text { monthly cost of living }\end{array}$ & $\begin{array}{c}\text { Number of } \\
\text { persons }\end{array}$ & Percentage \\
\hline In 10\% & 63 & $14.1 \%$ \\
\hline $10 \%-20 \%$ & 164 & $36.5 \%$ \\
\hline $20 \%-40 \%$ & 189 & $41.9 \%$ \\
\hline Over 40\% & 34 & $7.5 \%$ \\
\hline
\end{tabular}

\subsection{Overall measurement of Internet shopping addiction}

We designed seven problem items, seven problem items and five problem items to measure the three dimensions of Internet addiction, impulsive buying and compulsive buying (see table 1) And each item was assigned a score of 1,2,3,4, and 5(which indicated both how much the respondents agreed with the question and how much they were addicted to each item). The statistical results of mean and variance in table 6 below can be obtained by descriptive statistics of the scores of these three indexes with SPSS.

Table 6: Results of Internet shopping addiction among college students

\begin{tabular}{|c|c|c|c|c|}
\hline Indicators & sample size & mean value & Variance & Implications \\
\hline Internet addiction & 450 & 4.40 & 22.80 & Very Addictive \\
\hline Impulse buying & 450 & 3.72 & 33.71 & It's Serious \\
\hline Compulsive Buying & 450 & 1.98 & 20.17 & It's not obvious yet \\
\hline Online shopping addiction & 450 & 3.37 & 57.68 & It's kind of addictive \\
\hline
\end{tabular}


As can be seen from table 6, first of all, the average score for Internet addiction among college students is 4.4, which indicates that it is very close to the full score of 5, which means that the degree of Internet addiction among college students has been relatively high. Secondly, in the impulsive purchase, the average score of college students is 3.72, higher than the average level of 3 , indicating that the impulsive purchase of college students in a higher level. Finally, the average score for compulsive purchases was 1.98 , indicating that college students did not yet show strong desire for compulsive purchases. For Internet shopping addiction, its average score is 3.37, higher than the middle level of 3 points, indicating that college students have more obvious Internet shopping addiction, has reached a relatively addictive state.

\subsection{Comparative analysis of Internet shopping addiction among different groups}

In order to further analyze the distribution of Internet shopping addiction among college students, we try to make a comparative analysis of Internet shopping addiction between male and female students. Specifically, we will compare the performance of boys and girls in online shopping time, online shopping spending and online shopping addiction, and analyze whether there are significant differences between men and women. The program we used is the one-way Anova in SPSS. The results of the analysis are shown in Table 7.

Table 7: comparison results between men and women for online shopping

\begin{tabular}{|c|c|c|c|c|c|c|}
\hline & & $\begin{array}{l}\text { Sum Of } \\
\text { Squares }\end{array}$ & df & $\begin{array}{l}\text { Mean } \\
\text { Square } \\
\text { error }\end{array}$ & $\begin{array}{c}\text { F } \\
\text { Value }\end{array}$ & Significance \\
\hline \multirow{3}{*}{$\begin{array}{l}\text { About } \\
\text { shopping } \\
\text { time length }\end{array}$} & Intergroup & 2.591 & 1 & 2.591 & 3.842 & $0.053^{*}$ \\
\hline & $\begin{array}{l}\text { Within the } \\
\text { Group }\end{array}$ & 62.047 & 448 & 0.674 & & \\
\hline & Total & 64.638 & 449 & & & \\
\hline \multirow{3}{*}{$\begin{array}{c}\text { About } \\
\text { shopping } \\
\text { expense }\end{array}$} & Intergroup & 2551.358 & 1 & 2551.358 & 1.651 & 0.202 \\
\hline & $\begin{array}{l}\text { Within the } \\
\text { Group }\end{array}$ & 142189.886 & 448 & 1545.542 & & \\
\hline & Total & 144741.245 & 449 & & & \\
\hline \multirow{3}{*}{$\begin{array}{c}\text { About } \\
\text { shopping } \\
\text { addiction }\end{array}$} & Intergroup & 2730.448 & 1 & 2730.448 & 1.424 & 0.265 \\
\hline & $\begin{array}{l}\text { Within the } \\
\text { Group }\end{array}$ & 151189.346 & 448 & 1650.633 & & \\
\hline & Total & 153919.794 & 449 & & & \\
\hline
\end{tabular}

Note: * Means Below 0.1 at the significance level (P value)

The results of the comparison between groups in Table 7 showed that there was a significant difference in the time spent on online shopping between boys and girls ( $\mathrm{p}$ 0.1) . The time spent on online shopping by girls (mean 2.773) was significantly higher than that by boys (mean 2.440). In terms of the amount spent on online shopping (mean: 75.159 for men and 85.600 For women) and the overall level of online shopping addiction (mean: 3.32 for men and 3.40 for women), there was no significant difference between the male and female groups (the significant level was greater than 0.1). 
College Student's on-line Shopping Addiction: A Market Survey and Statistical Analysis

Therefore, the amount of monthly Internet shopping expenditure and the level of Internet shopping addiction did not differ by gender.

\subsection{Results}

(1) in terms of individual indicators, first of all, Internet addiction has become a significant problem among college students And the degree of Internet addiction of college students has been very high (average score of 4.4, has been very close to the full 5) this shows that the phenomenon of Internet addiction in Contemporary College students this group is very common, and relatively serious. Secondly, in the impulsive shopping, the average score of 3.72, has been higher than the median value of 3 points, which means that college students' impulsive shopping tendency has been basically formed, the degree of impulse is at a relatively obvious level. Finally, regarding the compulsive purchase, the overall situation is quite optimistic, the analysis result indicated that the university student compulsive purchase's score mainly concentrates in the middle and low sub-section, the average score is 1.98 , it shows that college students have not shown too obvious tendencies and habits in compulsive shopping.

(2) in the Comprehensive Index of Internet shopping addiction, the level of Internet shopping addiction of college students can be synthesized based on the survey scores of three dimensions of Internet addiction, impulsive purchase and compulsive purchase, and the final average score is 3.37 It has already exceeded the median value of 3 points, which indicates that college students, represented by the surveyed college students, as a whole, have shown an addiction to online shopping except for the initial phenomenon, but the degree of addiction is still in the Middle Level Has Not yet reached an unmanageable high range of values.

(3) in the comparative analysis of male and female students, the results show that: firstly, the mean value of the female students is significantly higher than that of the male students, which indicates that the female students spend more time on the online shopping behavior; secondly, on the amount of the online shopping expenses, there was no significant difference between the male and female groups, that is, the two groups had the same level of online shopping consumption. Finally, there was no significant difference in the level of online shopping addiction between male and female students, which indicates that college students as a whole have reached the level of online shopping addiction and the addiction was evident in both boys and girls, with no gender differences.

\section{Conclusion and implication}

Based on the results of the full-text statistical analysis, the basic conclusion is that the Internet shopping addiction of college students has taken shape initially and is currently at a medium level Therefore, students themselves, parents, schools, society and other relevant departments to pay attention to this in order to prevent this irrational behavior to continue to develop to a high level. In this regard, the author puts forward the following suggestions.

First of all, college students should start from their own, set up correct and positive online shopping motivation, rational online shopping, cultivate self-discipline, control the time of online shopping. Read more economic management books, form their own financial habits, when the emergence of online shopping addiction aura can make timely adjustments. 


\section{Shuai Tang and Dong-shan Yang}

Secondly, parents should communicate more with their children, fully understand their life shopping habits, while giving the necessary financial support, to timely intervention and correction of their bad shopping habits.

Thirdly, for schools, as the cradle of cultivating talents, it is not only the cultivation of knowledge, but also the cultivation of their living conditions and habits We can help college students develop a rational life style and a good sense of consumption by offering lectures on relevant knowledge, which is not only beneficial to students' school life It will also have a positive impact on social life after graduation.

Finally, there is a positive role for the social sector, particularly the media. Mass media can use the media to purify the social environment, promote mainstream values, create an upward "opinion environment", and create a series of public service advertisements aimed at the behavior of online shopping platforms To make college addicts understand that excessive online shopping will make them lose and miss out on some important people and things, which will exert a positive influence and guide their behavior.

\section{REFERENCES}

1. S.Chen, Development and psychometric characteristics of Chinese Internet addiction scale, Chinese Journal of Psychology, 3(2003) 112-124.

2. E.Hollander, Obsessive-compulsive related disorders, American Psychiatric Pub, (1993).

3. L.M.Koran, R.J.Faber, M.D.Large, et al., Estimated Prevalence of coercive Buying Behavior in the United States, The American Journal of Psychiatry, 163(10)(2006) 33-43.

4. S.H.Lee, R.J.Lennon and N.A.Rudd, Compulsive Consumption trends among Television Shoppers, Family and Consumer Sciences Research, 28(4)(2000) 22-34.

5. G.J.Meerkerk, R.J.Van Den Eijnden, A.A.Vermulst and H.F.Garretsen, The compulsive internet use scale (CIUS): some psychometric properties, Cyberpsychology \& behavior, 12(1)(2009) 1-6.

6. A.Mueller, J.E.Mitchell, L.A.Peterson, et al., Depression, materialism, and excessive Internet use in relation to compulsive buying, Comprehensive Psychiatry, 52(4)(2011) 420-424.

7. S.Rose and A.Dhandayudham, Towards an understanding of Internet-based problem shopping behaviour: The concept of online shopping addiction and its proposed predictors, Cyberpsychology \& behavior, 10(2)(2014) 140-153.

8. M.Shaw, and D.W.Black, Internet addiction, CNS drugs, 22(5)(2008) 353-365.

9. L.S.M.Whang, S.Lee and G.Chang, Internet over-users' psychological profiles: a behavior sampling analysis on internet addiction, Cyberpsychology \& behavior, 6(2)(2003) 143-150.

10. M.Zheng, Research on college students 'Internet shopping addiction and coping strategies, Hunan University, (2013). 